\title{
Authentic paternal parenting: The impact of family and environmental factors
}

Pinki Rani

Department of Human Development and Family Studies, I.C. Collage of Home Science, C.C.S. Haryana Agricultural Univesity, Hisar (Haryana) India

\section{ARTICLE INFO :}

$\begin{array}{lll}\text { Received } & : & 02.08 .2018 \\ \text { Revised } & : & 01.11 .2018 \\ \text { Accepted } & : & 05.11 .2018\end{array}$

\section{KEY WORDS :}

Maternal parenting style, Home environment, Emotional climate, Family integration

\section{HOW TO CITE THIS ARTICLE :}

Rani, Pinki (2018). Authentic paternal parenting: The impact of family and environmental factors. Adv. Res. J. Soc. Sci., 9 (2) : 141-148, DOI: 10.15740/ HAS/ARJSS/9.2/141-148.

Copyright@2018 : Hind Agri -

Horticultural Society

\begin{abstract}
The present investigation was carried out in Hisar district of Haryana state to find out the effects of home environment on paternal parenting style. From Hisar district two areas were selected i.e., urban and rural. The sample consist 100 girls between the age group of 7-8 years and their parents (both mother and father). 50 girls and their parents were selected randomly from Hisar city and 50 girls and their parents were selected randomly from rural area. A total of 50 boys between the age group of 7 to 8 years with both of their parents were selected randomly from each location. Hence, the total sample was 600 including ( 200 children and 400 their parents). Home observation for measurement of the environment (HOME) by Bradley and Caldwell (1984) and Parenting Style and Dimensions Questionnaire (PSDQ) by Robinson et al. (1995) were used to measure home environment and Parenting Style and Dimensions Questionnaire (PSDQ) by Robinson et al. (1995) was used to measure parenting style i.e. authoritative, authoritarian and permissive. Result revealed that aspects of home environment such as emotional climate $\left(\chi^{2}=8.72 *\right)$, learning material and opportunities $\left(\chi^{2}=6.78^{*}\right)$, enrichment $\left(\chi^{2}=12.66^{*}\right)$, family integration $\left(\chi^{2}=12.25^{*}\right)$ and composite home environment $\left(\chi^{2}=7.25^{*}\right)$ were significantly associated with father parenting style but, Responsivity $\left(\chi^{2}=1.30\right)$, encouragement of maturity $\left(\chi^{2}=4.87\right)$, family companionship $\left(\chi^{2}=3.60\right)$, and physical environment $\left(\chi^{2}=3.25\right)$ were non-significantly associated with father parenting style at 5 per cent level of significance. It was found that paternal parenting style were significantly associated with composite home environment and its aspects viz., encouragement of maturity, emotional climate, learning materials and opportunities, enrichment, family companionship and family integration $\left(\chi^{2}=19.97^{*}, 7.55^{*}, 18.73^{*}, 11.74^{*}, 16.12^{*}, 25.68^{*}, 7.29^{*}\right.$, respectively), but not significantly associated with responsivity $\left(\chi^{2}=5.48\right)$ and physical environment $\left(\chi^{2}=4.13\right)$.
\end{abstract}

